\title{
Plasma lipids in a London population and their relation to other risk factors for coronary heart disease
}

\author{
J. H. FULLER ${ }^{1}$, S. PINNEY, R. J. JARRETT, K. KILBOURN, AND H. KEEN \\ From the Unit for Metabolic Medicine, Department of Medicine, Guy's Hospital, London Bridge, London
}

SUMMARY Fasting plasma total cholesterol and triglyceride concentrations and high-density lipoprotein (HDL)-cholesterol concentrations have been measured in a random sample of 502 men and 503 women London local government employees, aged 16 to 64 years. In subjects aged 35 to 54 years, the frequency of 'hypercholesterolaemia', defined by one recently recommended criterion of plasma cholesterol $\geqslant 7 \cdot 1$ $\mathrm{mmol} / 1$, was 28.0 per cent in the men and 30.4 per cent in the women. The frequency of 'hypertriglyceridaemia' (plasma triglyceride $\geqslant 2.0 \mathrm{mmol} / \mathrm{l}$ ) in the same age group was 24.8 per cent for the men and 6.0 per cent for the women.

In the whole sample of 1005, there was no case of the WHO Type III lipoprotein abnormality and only one example of the WHO Type $\mathrm{V}$ abnormality. The method of spline function analysis showed unimodality in the two-dimensional cholesterol/triglyceride frequency distribution for both men and women. Using multiple regression analysis, total cholesterol was independently, positively related to $\log _{10}$-triglyceride, HDL-cholesterol, and age. $\log _{10}$-triglyceride was related positively to total cholesterol, body mass index, systolic blood pressure, uric acid, and fasting blood sugar in both sexes.

Mean HDL-cholesterol concentrations were significantly higher in women compared with men only in the 45 to 64 age range. By multiple regression analysis, HDL-cholesterol was independently positively related to total cholesterol and negatively related to $\log _{10}$-triglyceride in both sexes, and positively related to age in women.

Several long-term prospective studies (Kannel et al., 1971; Wilhelmsen et al., 1973; Reid et al., 1976) have conirmed the role of hypercholesterolaemia, hypertension, and cigarette smoking as independent factors predicting the increased likelihood of coronary heart disease. Other variables such as total triglyceride (Carlson and Böttiger, 1972), overweight (Kannel et al., 1967), blood glucose (Fuller et al., 1975), and uric acid (Stamler et al., 1972) may be related to the incidence of coronary heart disease, as may low levels of highdensity lipoprotein (Gordon et al., 1977).

The strong statistical relation of hyperlipidaemia to atherosclerotic heart disease, the primary cause of premature death in Western societies (Royal College of Physicians, 1976), and the hope of developing measures for its control, have been a major motivation in the recent expansion of research

\footnotetext{
1Present address: Department of Medical Statistics and Epidemiology, London School of Hygiene and Tropical Medicine, Keppel Street, London WC1E 7HT.

Received for publication 1 August 1977
}

into plasma lipoprotein structure, composition, and metabolism (Lewis, 1976). The quantitative study by ultracentrifugation of the plasma lipoproteins in large population groups is, however, both expensive and time consuming. In the present incomplete state of knowledge, the prevalence of hyperlipidaemia in the community, its relation with coronary heart disease and the specifications for the screening for and the treatment of hyperlipidaemia are probably most simply defined in terms of the plasma concentrations of total cholesterol, total triglyceride, and HDL-cholesterol (Fredrickson, 1975; Gordon et al., 1977). The present study describes the distribution of these lipid variables in a large group of London Local Government workers and their relations with other possible risk factors for coronary heart disease.

\section{Subjects and methods}

A random sample of 1005 subjects, stratified by age and sex, was drawn from employees of the Greater 
London Council and the Inner London Education Authority working in central London. The study was extended over the period February 1971 to May 1972 to investigate and allow for possible seasonal variations in the plasma lipid concentrations (Fuller et al., 1974). Known diabetics and pregnant women were excluded from the study.

Subjects attended a survey centre between 9.00 and $10.30 \mathrm{am}$ on the morning after being requested to fast for at least 12 hours. Standing height and weight were measured in indoor clothing and without shoes. Each individual had previously completed a general health questionnaire, including the WHO Cardiovascular questionnaire (Rose and Blackburn, 1968) and a dietary questionnaire, which were checked at interview. Blood pressure was measured with the subject in the sitting position using a standard sphygmomanometer, the diastolic pressure being taken as the point of muffling (phase 4). A capillary blood sample was taken from an ear lobe for the estimation of fasting whole blood sugar concentration by an automated microferricyanide reduction method (Technicon Method N-9a). All other estimations were carried out on a venous blood sample. The plasma cholesterol concentration was estimated by the Auto Analyser Method N-24a and plasma triglyceride concentration by a semiautomated fluorimetric method (Cramp and Robertson, 1968) using a Trilaurin Standard. The HDL-cholesterol concentration was obtained after precipitation of verylow-density lipoprotein (VLDL) and low-density lipoprotein (LDL) by dextran sulphate and calcium chloride (Burstein and Samaille, 1958).

Lipoprotein electrophoresis was performed on agarose gel (Noble, 1968) in all subjects and specific screening for 'floating-beta lipoprotein' was carried out, using preparative ultracentrifugation and subsequent electrophoresis, in a randomly selected subsample of 292 subjects.

Serum uric acid was estimated by the method of Lofland and Crouse (1965) and the following biochemical estimations were also carried out on serum samples: urea, creatinine, bilirubin, alkaline phosphatase, aspartate aminotransferase, albumin, globulin, calcium, iron, and protein-bound iodine. Haematological indices and the ABO and Rhesus blood groups were also determined. For all subjects, the body mass index (BMI), a measure of adiposity, was defined as weight $/(\text { height })^{2}$.

\section{Results}

The final co-operating study group of 502 men and 503 women represented 90 per cent of the original random sample. 95.8 per cent of the study group were of European origin. On biochemical screening, 3 subjects had abnormal levels of protein-bound iodine (1 low and 2 high), 3 subjects had high fasting blood sugars, 2 subjects had a high urea, and 2 subjects had abnormal liver function tests. These 10 individuals have been included in the analyses which follow.

Out of the whole group, 31.7 per cent of the men and 30.4 per cent of the women were current cigarette smokers. Of women in the age range 16 to $34,36 \cdot 0$ per cent were taking an oral contraceptive.

TOTAL LIPIDS AND HDL-CHOLESTEROL

Plasma total cholesterol concentrations were approximately normally distributed in both men and

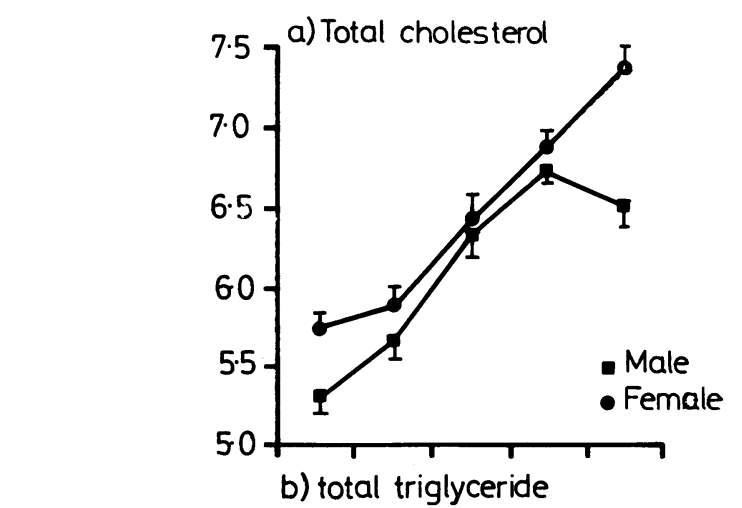

$\mathrm{mmol} / \mathrm{l}$
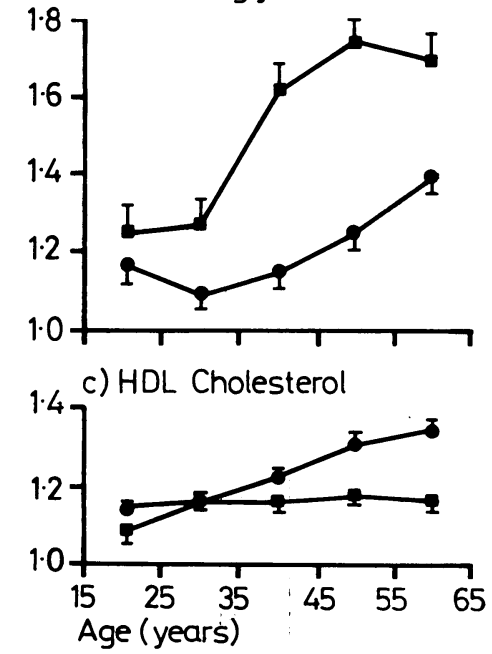

$$
\text { Number } \begin{array}{lllllc}
M & 90 & 99 & 101 & 113 & 99 \\
F & 91 & 95 & 106 & 111 & 100
\end{array}
$$

Fig. 1 Mean ( $\pm S E$ ) fasting plasma lipids by 10 year age groups. 


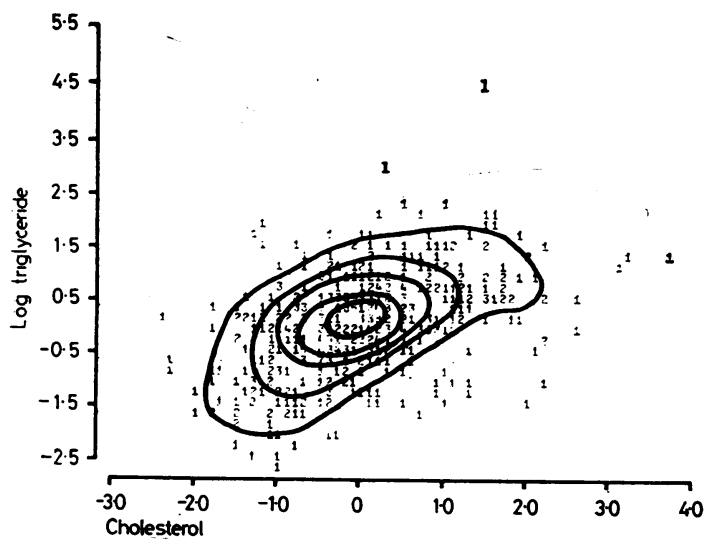

Fig. 2 Equal probability contours on the cholesterol/log 10 triglyceride probability distribution for men $(n=502)$ by spline function analysis (cholesterol and $\log _{10}$ triglyceride in standard deviation units).

women and the mean levels by 10-year age groups are shown in Fig. 1a. In both sexes mean cholesterol increased with age up to the 45 to 54 year agegroup. Above this age mean cholesterol increased for women, but decreased for men. The distribution of plasma total triglyceride concentration was slightly skewed to the right in both men and women and could be rendered approximately normal by log transformation.

Mean triglyceride levels for men were significantly higher than those for women in all age groups except the lowest (Fig. 1b). The mean HDLcholesterol concentration rose with age in women, but for the men changed little with age (Fig. 1c).

\section{ABNORMAL LIPOPROTEIN TYPES}

In the whole population of 1005 individuals, no examples of 'broad-beta' bands were detected on agarose gel lipoprotein electrophoresis. In one obese subject, fasting chylomicronaemia with an increased pre-beta band on electrophoresis was detected (WHO Type V abnormality).
In Fig. 2, the plasma cholesterol concentrations are plotted against log-triglyceride concentrations for the men only ( $n=502)$ to form a two-dimensional probability distribution. Contours of equal probability in this distribution are plotted using the method of spline function analysis, a data smoothing technique (Boneva et al., 1971). This method did not indicate any sub-clusters of individuals in the cholesterol/triglyceride probability distribution. Similar results were obtained for the women.

\section{ASSOCIATED FACTORS}

In Table 1 are shown the simple correlation coefficients, for men and women separately, between the following variables: total cholesterol, $\log _{10}-$ triglyceride, HDL-cholesterol, age, BMI, systolic blood pressure, fasting blood sugar, and uric acid.

These same variables have been used in a forward stepwise multiple regression analysis (Dixon, 1970) with total cholesterol, $\log _{10}$-triglyceride, and HDL-cholesterol as the dependent variables (Table 2). In both sexes, total cholesterol was significantly and independently positively related to $\log _{10}$-triglyceride, HDL-cholesterol, and age. When used as the dependent variable, $\log _{10-}$ triglyceride was positively related to total cholesterol, BMI, systolic blood pressure, uric acid, and fasting blood sugar in both sexes, but negatively related to age in women and negatively related to HDLcholesterol in men. HDL-cholesterol was significantly, independently and positively related to total cholesterol, but negatively related to $\log _{10^{-}}$ triglyceride in both sexes and was positively related to age in women.

\section{Discussion}

\section{TOTAL CHOLESTEROL AND TRIGLYCERIDE}

In considering the role of the plasma lipids as risk factors for coronary heart disease, particularly in the context of possible therapeutic intervention, definitions of their 'normal' or 'desirable' ranges must

Table 1 Correlation matrix (includes only subjects with complete information)

\begin{tabular}{|c|c|c|c|c|c|c|c|c|}
\hline 456 men 449 women & $\begin{array}{l}\text { Total } \\
\text { cholesterol }\end{array}$ & $\begin{array}{l}\log _{10} \\
\text { triglyceride }\end{array}$ & $\begin{array}{l}\text { HDL } \\
\text { cholesterol }\end{array}$ & $B M I$ & Age & Systolic BP & Uric acid & $\begin{array}{l}\text { Fasting } \\
\text { blood sugar }\end{array}$ \\
\hline $\begin{array}{l}\text { Total cholesterol } \\
\text { Log }_{10} \text { triglyceride } \\
\text { HDL cholesterol } \\
\text { BMI } \\
\text { Age } \\
\text { Systolic BP } \\
\text { Uric acid } \\
\text { Fasting blood sugar }\end{array}$ & $\begin{array}{l}0.53 \ddagger \\
0.34 \ddagger \\
0.30 \ddagger \\
0.40 \ddagger \\
0.17 \star \\
0.08 \\
0.23 \ddagger\end{array}$ & $\begin{array}{l}0.26 \ddagger \\
0.08 \\
0.39 \ddagger \\
0.30 \ddagger \\
0.30 \ddagger \\
0.24 \ddagger \\
0.33 \ddagger\end{array}$ & $\begin{array}{l}0.49 \ddagger \\
0.05 \\
0.05 \\
0.06 \\
0.04 \\
0.03 \\
0.07\end{array}$ & $\begin{array}{l}0.12 \\
0.25 \ddagger \\
0.05 \\
0.33 \ddagger \\
0.26 \ddagger \\
0.29 \ddagger \\
0.33 \ddagger\end{array}$ & $\begin{array}{l}0.47 \ddagger \\
0.17 \star \\
0.30 \ddagger \\
0.36 \ddagger \\
0.26 \ddagger \\
0.03 \\
0.19 \ddagger\end{array}$ & $\begin{array}{l}0.30 \ddagger \\
0.30 \ddagger \\
0.13 \star \\
0.25 \ddagger \\
0.52 \ddagger \\
0.18 \ddagger \\
0.19 \ddagger\end{array}$ & $\begin{array}{l}0.08 \\
0.24 \ddagger \\
0.03 \\
0.31 \ddagger \\
0.18 \star \\
0.23 \ddagger \\
0.17\end{array}$ & $\begin{array}{l}0.17^{\star} \\
0.20 \dagger \\
0.11 \\
0.14^{\star} \\
0.23 \ddagger \\
0.22 \dagger \\
0.12\end{array}$ \\
\hline
\end{tabular}

Men

$\star P<0.05, \dagger P<0.01, \ddagger P<0.001$. 
Table 2 Multiple regression analysis: Dependent variables: total cholesterol, $\log _{10}$ triglyceride, $H D L$ cholesterol ( $\mathrm{mmol} / \mathrm{l}$ )

\begin{tabular}{|c|c|c|c|}
\hline \multirow{2}{*}{$\begin{array}{l}\text { Dependent } \\
\text { variable }\end{array}$} & \multirow{2}{*}{$\begin{array}{l}\text { Independent } \\
\text { variable }\end{array}$} & \multicolumn{2}{|l|}{$t$ values } \\
\hline & & $\begin{array}{l}\text { Men } \\
(n=456)\end{array}$ & $\begin{array}{l}\text { Women } \\
(n=449)\end{array}$ \\
\hline $\begin{array}{l}\text { Total } \\
\text { cholesterol }\end{array}$ & $\begin{array}{l}\log _{10} \text {-triglyceride } \\
\text { HDL-cholesterol } \\
\text { Age }\end{array}$ & $\begin{array}{r}11 \cdot 6 \ddagger \\
8 \cdot 0 \ddagger \\
6 \cdot 7_{+}^{\ddagger}\end{array}$ & $\begin{array}{l}5 \cdot 1_{ \pm}^{+} \\
9 \cdot 9_{+}^{+} \\
8 \cdot 2 \pm\end{array}$ \\
\hline $\begin{array}{l}\log _{10^{-}} \\
\text {triglyceride }\end{array}$ & $\begin{array}{l}\text { Total cholesterol } \\
\text { HDL-cholesterol } \\
\text { BMI } \\
\text { Systolic BP } \\
\text { Uric acid } \\
\text { Fasting blood sugar } \\
\text { Age }\end{array}$ & $\begin{array}{r}11 \cdot 1_{\ddagger}^{\ddagger} \\
-2 \cdot 6^{\star} \\
3 \cdot 4_{+}^{\ddagger} \\
3 \cdot 7_{\ddagger}^{\ddagger} \\
2 \cdot 9^{\dagger} \\
3 \cdot 6_{\ddagger}^{\ddagger} \\
0 \cdot 3^{\ddagger}\end{array}$ & $\begin{array}{r}4 \cdot 6_{+}^{\ddagger} \\
-1 \cdot 7^{+} \\
3 \cdot 6_{+}^{+} \\
4 \cdot 2_{+}^{+} \\
2 \cdot 9^{\dagger} \\
2 \cdot 4^{\star} \\
-2 \cdot 8^{\dagger}\end{array}$ \\
\hline $\begin{array}{l}\text { HDL- } \\
\text { cholesterol }\end{array}$ & $\begin{array}{l}\text { Total cholesterol } \\
\text { Log }_{10} \text {-triglyceride } \\
\text { Age }\end{array}$ & $\begin{array}{l}7 \cdot 9+ \\
-2 \cdot 6 \dagger \\
-1 \cdot 4\end{array}$ & $\begin{array}{r}9 \cdot 9_{ \pm}^{\ddagger} \\
-2 \cdot 2^{\star} \\
2 \cdot 1^{\star}\end{array}$ \\
\hline
\end{tabular}

$\star P<0.05,+P<0.01, \ddagger P<0.001$.

take into account the well-recognised variation with age and sex of both cholesterol and triglyceride (Schilling et al., 1969; Wood et al., 1972; Gibson and Whorton, 1973) and the variation introduced by differences in laboratory methods between studies (Whitehead et al., 1973; Castelli et al., 1977a).

In this population group, the rise in the mean total cholesterol with age, followed by a decline for men in the age group 55 to 64 years (Fig. 1a) agrees well with the findings of several other studies, as reviewed by Carlson and Lindstedt (1969). Compared with another London based study of factory workers (Lewis et al., 1974), in which the same laboratory methods for total lipid determinations were used, the women had higher cholesterol levels at all ages and the men had higher mean cholesterols above the age of 40 years. The mean cholesterol levels in our men were also somewhat higher than those found in a study of healthy men in the Glasgow conurbation (Lorimer et al., 1974), but were in general lower than those found in the Stockholm Prospective Study (Carlson and Lindstedt, 1969). The cholesterol levels in women resembled those found in Swedish studies (Carlson and Lindstedt, 1969; Bengtsson et al., 1974).

In middle-aged men, mean triglyceride levels increased with age group (Fig. 1b) and then reached a plateau, whereas in women there was a less pronounced rise with age group. Triglyceride levels in both sexes were much higher than in the London factory workers (Lewis et al., 1974), but were similar to levels found in Scandinavian studies iCarlson and Lindstedt, 1969; Bengtsson et al., 1974; Thelle et al., 1976).

Plasma total lipid concentrations are dependent on the concentrations and compositions of the plasma lipoproteins. The presently accepted classification of the hyperlipoproteinaemias is that of Fredrickson et al. (1967), subsequently modified by a WHO Committee (Beaumont et al., 1970), and is based upon the pattern after qualitative separation of lipoproteins by paper or agarose electrophoresis. In some classifications, cutting points for lipoprotein concentrations have been derived as centiles of their distributions in the population (Lewis et al., 1974). However, such cutting points are always arbitrary since the majority of population studies (Castelli et al., 1977a) demonstrate unimodal, albeit skewed, distributions of lipids and lipoproteins.

In this study, the 90th centile points in the distribution of total cholesterol in men were $6.7 \mathrm{mmol} / 1$ for the age group 16 to 34 years and $8.0 \mathrm{mmol} / 1$ for the age group 35 to 54 years. Corresponding levels for women were $7.5 \mathrm{mmol} / 1$ and $8.2 \mathrm{mmol} / 1$, respectively. The triglyceride $90 \mathrm{th}$ centile points were, for the men, $1.8 \mathrm{mmol} / 1$ in the 16 to 34 year age group and $2.6 \mathrm{mmol} / 1$ in the 35 to 54 year age group; corresponding values for the women were lower, $1.7 \mathrm{mmol} / 1$ and $1.7 \mathrm{mmol} / 1$, respectively. These centile points are generally higher than those derived from total lipid distributions in the London factory workers (Lewis et al., 1974).

In the present study, the unimodality of the distributions of both total cholesterol and triglyceride is confirmed by the method of spline function analysis (Fig. 2). The probability contours in the cholesterol/triglyceride frequency distribution do not indicate any heterogeneity in the data, as might be expected if there were any significant clustering of individuals into groups with the common WHO lipoprotein abnormalities (Beaumont et al., 1970), viz. subjects with raised cholesterol alone (Type IIa), raised triglyceride alone (Type IV), or increases in both (Type IIb). The disadvantages of defining abnormal lipoprotein types by arbitrary cut-off points have been discussed in detail by Olsson and Carlson (1975), a major factor being that the relative frequencies of the lipoprotein abnormalities are highly dependent on relatively small changes in the cut-off values. This applies particularly to the WHO Type IIb abnormality (Carlson, 1976).

The current classification of the hyperlipoproteinaemias is not an aetiological one and correlates poorly with the results of genetic studies (Hazzard et al., 1973). Clarification of the metabolic interrelations of the lipoproteins and the role of the apoproteins (Eisenberg, 1976) will no doubt eventually lead to a more fundamental classification. 
Table 3 Frequency of CHD risk factor combinations for age group 35 to 54 years

\begin{tabular}{|c|c|c|}
\hline Risk factors & $\begin{array}{l}\text { Men } \\
(n=214)\end{array}$ & $\begin{array}{l}\text { Women } \\
(n=217)\end{array}$ \\
\hline Cholesterol $\geqslant 7.1 \mathrm{mmol} / 1$ & $28.0 \%$ & $30 \cdot 4 \%$ \\
\hline Triglyceride $\geqslant 2.0 \mathrm{mmol} / 1$ & $24 \cdot 8 \%$ & $6.0 \% \dagger$ \\
\hline Cholesterol $\geqslant 7.8 \mathrm{mmol} / 1$ & $14.0 \%$ & $15 \cdot 2 \%$ \\
\hline Triglyceride $\geqslant 2.3 \mathrm{mmol} / 1$ & $15 \cdot 0 \%$ & $2 \cdot 8 \% \dagger$ \\
\hline Both lipids above lower limits & $10 \cdot 7 \%$ & $2 \cdot 3 \% \dagger$ \\
\hline Both lipids above upper limits & $4 \cdot 7 \%$ & $0.5 \% \star$ \\
\hline Cigarette smoker & $28.0 \%$ & $32 \cdot 7 \%$ \\
\hline Diastolic $\mathrm{BP} \geqslant 100 \mathrm{mmHg}$ & $7 \cdot 9 \%$ & $3 \cdot 7 \%$ \\
\hline $\begin{array}{l}\text { Cholesterol } \geqslant 7 \cdot 1 \mathrm{mmol} / 1 \text { and } \\
\text { cigarette smoker }\end{array}$ & $7 \cdot 0 \%$ & $10 \cdot 6 \%$ \\
\hline $\begin{array}{c}\text { Cholesterol } \geqslant 7 \cdot 1 \mathrm{mmol} / 1 \text { and } \\
\text { diastolic } \mathrm{BP} \geqslant 100 \mathrm{mmHg}\end{array}$ & $3 \cdot 3 \%$ & $1 \cdot 8 \%$ \\
\hline $\begin{array}{l}\text { Diastolic } B P \geqslant 100 \mathrm{mmHg} \text { and } \\
\text { cigarette smoker }\end{array}$ & $2 \cdot 3 \%$ & $1 \cdot 4 \%$ \\
\hline $\begin{array}{l}\text { Cholesterol } \geqslant 7.1 \mathrm{~mm} / / 1 \text { and } \\
\text { diastolic } \mathrm{BP} \geqslant 100 \mathrm{mmHg} \text { and } \\
\text { cigarette smoker }\end{array}$ & $0.9 \%$ & $0.5 \%$ \\
\hline
\end{tabular}

Men/Women significant difference. ${ }^{\star} P<0.01,+P<0.001$.

system which can then be applied in population studies.

In Table 3 are shown the proportions of men and women aged 35 to 54 who would be considered hyperlipidaemic by some recently recommended criteria (Royal College of Physicians, 1976). The frequency of 'hypercholesterolaemia' in men doubles from 14.0 to 28.0 per cent, as the cutting point for cholesterol is reduced from $7 \cdot 8$ to $7 \cdot 1 \mathrm{mmol} / 1$. In women, the corresponding change in rates is very similar from 15.2 to 30.4 per cent. A change in triglyceride criterion from 2.3 to 2.0 $\mathrm{mmol} / \mathrm{l}$ produces an increase in 'hypertriglyceridaemia' from 15.0 to 24.8 per cent in men, and an increase from 2.8 to 6.0 per cent in women. Of the men, 4.7 per cent and of the women, 0.5 per cent had lipid concentrations both of which exceeded the higher cutting points and 10.7 and 2.3 per cent, respectively, exceeded both lower points. Based on the variation in the frequency of coronary heart disease among different populations and the associated levels of total cholesterol concentration, an upper limit of $6.2 \mathrm{mmol} / 1(240 \mathrm{mg} / \mathrm{dl})$ for 'desirable' or 'optimal' cholesterol levels has been recommended (Wright, 1976). Using this criterion, some 62.1 per cent of the men and 64.5 per cent of the women in this study aged 35 to 54 would be considered to have 'undesirable' cholesterol levels.

ASSOCIATIONS WITH OTHER 'RISK FACTORS' The significance of given concentrations of plasma lipids in the prediction of coronary heart disease and so the setting of 'cutting points' is complicated by the probable interaction with the other major risk factors for coronary heart disease, hypertension, and cigarette smoking (Rose, 1976). The proportions of men and women aged 35 to 54 with plasma cholesterol exceeding $7 \cdot 1$ or $7.8 \mathrm{mmol} / \mathrm{l}$, diastolic blood pressure greater than $100 \mathrm{mmHg}$, and who were current cigarette smokers are shown in Table 3 , together with the frequencies of various combinations of these characteristics.

Furthermore, the plasma lipids correlate significantly with several other factors which may well play some part in the genesis and development of coronary heart disease. Several of the relations shown in the correlation matrix in Table 1 are distinctly interdependent and a more satisfactory representation of the independent relation between these variables is obtained by multiple regression analysis (Table 2) in which total cholesterol, $\log _{10}$-triglyceride, and HDL-cholesterol are taken in turn as the dependent variable.

The significant positive correlation between total cholesterol and $\log _{10}$-triglyceride concentrations, independent of age, confirms the findings in other studies (Carlson and Lindstedt, 1969). In some populations, positive correlations have also been shown between cholesterol and blood pressure (Bulpitt et al., 1976), and Carlson and Lindstedt (1969) have reviewed the relation between cholesterol and measures of obesity. However, many studies have not considered the possible confounding positive relation of triglyceride with both blood pressure and obesity; when such allowance was made in this study by multiple regression analysis (Table 2), no independent correlation of cholesterol with blood pressure or BMI was demonstrable. The independent correlation of $\log _{10}$-triglyceride with blood pressure, BMI, blood sugar, and uric acid is also shown in Table 2. These multiple relations may, in part, explain the uncertainty about the role of the plasma triglyceride as an independent risk factor for coronary heart disease (Carlson and Böttiger, 1972; Wilhelmsen et al., 1973; Gordon et al., 1977).

\section{HIGH-DENSITY LIPOPROTEIN}

Interest in the association between low plasma concentrations of $\mathrm{HDL}$ and the prevalence of coronary heart disease has been recently revived (Miller and Miller, 1975). Glomset (1968) has proposed that HDL is involved in the removal of cholesterol from peripheral tissues and its transport to the liver. The removal of cholesterol from human skin fibroblasts has been shown to be enhanced by HDL (Stein and Stein, 1976) and the uptake of LDL by porcine arterial smooth-muscle cells is decreased by HDL (Carew et al., 1976). Several studies have shown a relation between low plasma HDL levels and prevalence of coronary heart disease (Albers et al., 1976; Rhoads et al., 1976; Castelli et al., 1977b) and in the Framingham Study, 
HDL-cholesterol is a potent predictive factor for coronary heart disease incidence in men and women over the age of 50 years, statistically independent of total cholesterol, triglyceride, and other established risk factors (Gordon et al., 1977).

In this study, HDL-cholesterol was measured by a precipitation method and these methods have been shown to give results correlating well with those obtained with preparative ultracentrifugation (Ononogbu and Lewis, 1976). The levels of HDLcholesterol (Fig. 1c) were similar in men, and slightly lower in women, compared with those from other studies using precipitation techniques (Castelli et al., 1977a), but tended to be lower in both sexes than the values obtained in studies using preparative ultracentrifugation (Lewis et al., 1974; Carlson and Ericsson, 1975).

Several studies (Carlson and Ericsson, 1975; Albers et al., 1976) have shown increased HDLcholesterol levels in premenopausal women who enjoy relative immunity from coronary heart disease. However, in our study, only women in the age range 45 to 64 years had significantly increased HDL-cholesterol levels $(P<0.01)$ compared with the men.

Using multiple regression analysis (Table 2), a significant inverse relation between HDLcholesterol and triglyceride was found in men and women, confirming the findings of other studies (Albers et al., 1976; Carlson, 1976; Castelli et al., 1977a). There was also a positive independent relation between HDL-cholesterol and total cholesterol in both sexes. In other studies, the association between HDL-cholesterol and either total or LDL-cholesterol has varied between positive, negative, or non-significant (Albers et al., 1976; Carlson, 1976; Rhoads et al., 1976; Gordon et al., 1977).

In a study of 52 Jamaican middle-aged men (Miller et al., 1976), multiple regression analysis showed a significant inverse relation between HDL-cholesterol on the one hand and LDLcholesterol, total triglyceride, and diastolic blood pressure on the other. However, this population was heterogeneous, consisting of two groups of 27 urban and 25 rural workers whose mean weight, plasma lipids, and blood glucose were significantly different. In the present study, HDL-cholesterol was not found to be significantly related to blood pressure, BMI, fasting blood sugar, or uric acid (Table 2).

The importance of $\mathrm{HDL}$ as an independent predictive factor for coronary heart disease is rapidly becoming apparent and its incorporation in the coronary heart disease 'risk profile' is being recommended (Gordon et al., 1977). The distribu- tions of HDL concentrations in various populations, its associations with other 'risk factors' for coronary heart disease, and the effect on HDL of various therapeutic measures, are, therefore, important questions in the study of the pathogenesis, treatment, and prevention of atherosclerotic heart disease.

We thank the late Dr A. B. Stewart, Dr G. Wigley, Dr T. Hall, Mr R. Coulter, and the medical staff of the Greater London Council for making this study possible; Dr R. Carpenter, Mr P. McCartney, Mr M. McCartney, Miss J. Bailey for statistical and data processing advice, Prof. T. Whitehead for biochemical analyses, $\mathrm{Dr} P$. Barkhan for haematological analyses, Dr J. Slack and Mrs N. Noble for ultracentrifugation analyses, and, finally, all the subjects who took part in the study. J.H.F. and the costs of the study were supported by a grant from the Medical Research Council.

\section{References}

Albers, J. J., Wahl, P. W., Cabana, V. G., Hazzard, W. R., and Hoover, J. J. (1976). Quantitation of apolipoprotein A-I of human plasma high density lipoprotein. Metabolism, 25, 633-644.

Beaumont, J. L., Carlson, L. A., Cooper, G. R., Fejfar, Z., Fredrickson, D. S., and Strasser, T. (1970). Classification of hyperlipidaemias and hyperlipoproteinaemias. Bulletin of the World Health Organization, 43, 891-915.

Bengtsson, C., Tibblin, E., Blohmé, G., and Gustafson, A. (1974.) Serum cholesterol and serum triglycerides in middle-aged women. Scandinavian fournal of Clinical and Laboratory Investigation, 34, 61-66.

Boneva, L. I., Kendall, D., and Stefanov, I. (1971). Spline transformations: three new diagnostic aids for the statistical data analyst. Fournal of the Royal Statistical Society (Series B), 33, 1-70.

Bulpitt, C. J., Hodes, C., and Everitt, M. G. (1976). The relationship between blood pressure and biochemical risk factors in a general population. British fournal of Preventive and Social Medicine, 30, 158-162.

Burstein, M., and Samaille, J. (1958). Sur une nouvelle méthode de dosage du cholestérol lié aux $\alpha$ et aux $\beta$ lipoprotéines du sérum (in French). Clinica Chimica Acta, 3, 320-327.

Carew, T. E., Koschinsky, T., Hayes, S. B., and Steinberg, D. (1976). A mechanism by which high-density lipoproteins may slow the atherogenic process. Lancet, 1, 1315-1317.

Carlson, L. A. (1976). Lipid composition of the major human serum lipoprotein density classes in different types of hyperlipoproteinaemia. In Lipoprotein Metabolism, pp. 6979. Ed. by H. Greten. Springer-Verlag, Berlin.

Carlson, L. A., and Böttiger, L. E. (1972). Ischaemic heart disease in relation to fasting values of plasma triglycerides and cholesterol. Lancet, 1, 865-868.

Carlson, L. A., and Ericsson, M. (1975). Quantitative and qualitative serum lipoprotein analysis. Part 1 . Studies in healthy men and women. Atherosclerosis, 21, 417-433.

Carlson, L. A., and Lindstedt, S. (1969). The Stockholm Prospective Study 1. The initial values for plasma lipids. Acta Medica Scandinavica, 185, Suppl. 493, pp. 135.

Castelli, W. P., Cooper, G. R., Doyle, J. T., Garcia-Palmieri, 
M., Gordon, T., Hames, C., Hulley, S. B., Kagan, A., Kuchmak, M., McGee, D., and Vicic, W. J. (1977a). Distribution of triglyceride and total, LDL and HDL cholesterol in several populations: a cooperative lipoprotein phenotyping study. Fournal of Chronic Diseases, 30, 147-169.

Castelli, W. P., Doyle, J. T., Gordon, T., Hames, C. G., Hjortland, M. C., Hulley, S. B., Kagan, A., and Zukel, W. J. (1977b). HDL cholesterol and other lipids in coronary heart disease. Circulation, 55, 767-772.

Cramp, D. C., and Robertson, G. (1968). The fluorometric assay of triglyceride by a semiautomated method. Analytical Biochemistry, 25, 246-251.

Dixon, W. J. (1970). Biomedical Computer Programs. University of California Press, Berkeley.

Eisenberg, S. (1976). Lipoprotein metabolism and hyperlipidaemia. In Atherosclerosis Reviews, Vol. 1, p. 23. Ed. by R. Paoletti and A. M. Gotto. Raven Press, New York.

Fredrickson, D. S. (1975). It's time to be practical. Circulation, 51, 209-211.

Fredrickson, D. S., Levy, R. I., and Lees, R. S. (1967). Fat transport in lipoproteins-An integrated approach to mechanisms and disorders. New England fournal of Medicine, 276, 34-44, 94-103, 148-156, 215-225, and 273-281.

Fuller, J. H., Grainger, S. L., Jarrett, R. J., and Keen, H. (1974). Possible seasonal variation of plasma lipids in a healthy population. Clinica Chimica Acta, 52, 305-310.

Fuller, J. H., McCartney, P., and Colwell, L. M. (1975). Blood sugar as a predictor for coronary heart disease (abstract). Diabetologia, 11, 343.

Gibson, T. C., and Whorton, E. B. (1973). The prevalence of hyperlipidemia in a natural community. Fournal of Chronic Diseases, 26, 227-236.

Glomset, J. A. (1968). The plasma lecithin: cholesterol acyltransferase reaction. Fournal of Lipid Research, 9, 155-167.

Gordon, T., Castelli, W. P., Hjortland, M. C., Kannel, W. B., and Dawber, T. R. (1977). High density lipoprotein as a protective factor against coronary heart disease. American fournal of Medicine, 62, 707-714.

Hazzard, W. R., Goldstein, J. L., Schrott, H. G., Motulsky, A. G., and Bierman, E. L. (1973). Hyperlipidaemia in coronary heart disease. III. Evaluation of lipoprotein phenotypes of 156 genetically defined survivors of myocardial infarction. Fournal of Clinical Investigation, 52, 1569-1577.

Kannel, W. B., Castelli, W. P., Gordon, T., and McNamara, P. M. (1971). Serum cholesterol, lipoproteins and the risk of coronary heart disease. The Framingham Study. Annals of Internal Medicine, 74, 1-12.

Kannel, W. B., LeBauer, E. J., Dawber, T. R., and McNamara, P. M. (1967). Relation of bodyweight to development of coronary heart disease. The Framingham Study. Circulation, 35, 734-744.

Lewis,-B. (1976). The Hyperlipidaemias. Blackwell, Oxford.

Lewis, B., Chait, A., Wootton, I. D. P., Oakley, C. M., Krikler, D. M., Sigurdsson, G., February, A., Maurer, B., and Birkhead, J. (1974). Frequency of risk factors for ischaemic heart disease in a healthy British population with particular reference to serum-lipoprotein levels. Lancet, 1, 141-146.

Lofland, H. B., and Crouse, L. (1965). An automated procedure for uric acid determination using the cupric phenanthroline method. In Automation in Analytical Chemistry, Technicon Symposia 1965, p. 356. Ed. by L. T. Skeggs. Mediad, New York.

Lorimer, A. R., Cox, F. C., Greaves, D. A., Jubb, J. S., Hawthorne, V. M., Morgan, H. G., and Lawrie, T. D. V. (1974). Prevalence of hyperlipoproteinaemia in apparently healthy men. British Heart fournal, 36, 192-196.

Miller, G. J., and Miller, N. E. (1975). Plasma-high-densitylipoprotein concentration and development of ischaemic heart disease. Lancet, 1, 16-19.

Miller, G. J., Miller, N. E., and Ashcroft, M. T. (1976). Inverse relationship in Jamaica between plasma highdensity lipoprotein cholesterol concentration and coronarydisease risk as predicted by multiple risk-factor status. Clinical Science and Molecular Medicine, 51, 475-482.

Noble, R. P. (1968). Electrophoretic separation of plasma lipoproteins in agarose gel. Fournal of Lipid Research, 9, 693-700.

Olsson, A. G., and Carlson, L. A. (1975). Studies in asymptomatic primary hyperlipidaemia. 1. Types of hyperlipoproteinaemias and serum lipoprotein concentrations, compositions and interrelations. Acta Medica Scandinavica, 198, Suppl. 580, pp. 37.

Ononogbu, I. C., and Lewis, B. (1976). Lipoprotein fractionation by a precipitation method. A simple quantitative procedure. Clinica Chimica Acta, 71, 397-402.

Reid, D. D., Hamilton, P. J. S., McCartney, P., Rose, G., Jarrett, R. J., and Keen, H. (1976). Smoking and other risk factors for coronary heart disease in British civil servants. Lancet, 2, 979-984.

Rhoads, G. G., Gulbrandsen, C. L., and Kagan, A. (1976). Serum lipoproteins and coronary heart disease in a population study of Hawaii Japanese men. New England fournal of Medicine, 294, 293-298.

Rose, G. (1976). Detection of high coronary risk. Postgraduate Medical fournal, 52, 452-455.

Rose, G. A., and Blackburn, H. (1968). Cardiovascular survey methods. World Health Organization. Monograph Series, No. 56, p. 172.

Royal College of Physicians of London and British Cardiac Society (1976). Prevention of coronary heart disease. fournal of the Royal College of Physicians of London, 10, 213-275.

Schilling, F. J., Christakis, G., Orbach, A., and Becker, W. H. (1969). Serum cholesterol and triglyceride. An epidemiological and pathogenetic interpretation. American fournal of Clinical Nutrition, 22, 133-138.

Stamler, J., Berkson, D. M., and Lindberg, H. A. (1972). Risk factors: their role in the aetiology and pathogenesis of the atherosclerotic diseases. In The Pathogenesis of Atherosclerosis, p. 41. Ed. by R. W. Wissler and J. C. Geer. Williams and Wilkins, Baltimore.

Stein, Y., and Stein, O. (1976). Cholesterol removal in isolated cells and in tissue culture. Triangle (En.), 15, 63-69.

Thelle, D. S., Førde, O. H., Try, K., and Lehmann, E. H. (1976). The Tromsø Heart Study. Acta Medica Scandinavica, 200, 107-118.

Whitehead, T. P., Browning, D. M., and Gregory, A. (1973). A comparative survey of the results of analyses of blood serum in clinical chemistry laboratories in the United Kingdom. Fournal of Clinical Pathology, 26, 435-445.

Wilhelmsen, L., Weden, H., and Tibblin, G. (1973). Multivariate analysis of risk factors for coronary heart disease. Circulation, 48, 950-958.

Wood, P. D. S., Stern, M. P., Silvers, A., Reaven, G. M. and von der Groeben, J. (1972). Prevalence of plasma lipoprotein abnormalities in a free-living population of the Central Valley, California. Circulation, 45, 114-126.

Wright, I. S. (1976). Correct levels of serum cholesterol fournal of the American Medical Association, 236, 261-262.

Requests for reprints to Dr J. H. Fuller, Department of Medical Statistics and Epidemiology, London School of Hygiene and Tropical Medicine, Keppel Street, London WC1E 7HT. 